\title{
The role of podcasting in effective curriculum renewal
}

\author{
Ming Nie ${ }^{\mathrm{a} *}$, Alejandro Armellini ${ }^{\mathrm{a}}$, Sue Harrington ${ }^{\mathrm{b}}$, Kelly Barklamb ${ }^{\mathrm{b}}$ and \\ Ray Randall ${ }^{\mathrm{b}}$ \\ ${ }^{a}$ Beyond Distance Research Alliance, University of Leicester, Leicester, UK; ${ }^{b}$ School of \\ Psychology, University of Leicester, Leicester, UK
}

(Received 17 February 2010; final version received 27 April 2010)

\begin{abstract}
This paper reports on a case study into the contribution of podcasting to the curriculum transformation of two distance-taught master's programmes. Both programmes attract work-based Occupational Psychology practitioners, most of whom are in full-time employment. Challenges faced by the course team included adding flexibility to the curricula, increasing learner engagement (both with learning materials and feedback) and reducing learner isolation. As part of a coordinated enhancement effort, which included changes to curriculum design and delivery, 59 podcasts were introduced into the curriculum over a 12-month period. Qualitative and quantitative data were gathered from students and staff throughout the study. Action research ensured a regular flow of relevant evidence informing each stage of the renewal process. Evidence suggested that the students' learning experiences improved as a result of four key benefits associated with the integration of podcasting in learning design: personalisation; an additional and different format for providing clear and engaging guidance, support and feedback; increased flexibility and mobility within the curricula; and 'design once, deliver many times' with minimum adaptation.
\end{abstract}

Keywords: action research; curriculum design; curriculum delivery; curriculum renewal; occupational psychology; institutional transformation; learning design; podcasting

\section{Introduction}

This paper reports on a study of the contribution of podcasting to curriculum transformation at the University of Leicester, UK. We discuss the challenges of delivering distance learning courses faced by the Occupational Psychology (OP) team and how these were addressed by a range of coordinated curriculum design and delivery measures. Within those measures, we focus on the contribution of podcasting to the transformation of the OP curricula. In this study, the term 'podcast' is used to refer to a digital media file that plays sound or video, and that is available from a website for playback on a portable device (Salmon et al. 2008). In the light of earlier research, we evaluate the potential of podcasting in distance education. We describe our research methods and demonstrate how the podcasts were developed and integrated into the two OP curricula. We present and discuss our key findings. We conclude by contextualising the impact of this research on curriculum renewal at an institutional level.

*Corresponding author. Email: mn79@leicester.ac.uk 


\section{Background}

Podcasting captured the attention of academics in higher education in 2005. In the USA, one of the first initiatives involving extensive use of podcasting began at Duke University, ${ }^{1}$ where first-year students were given iPods for listening to podcasting applications that included course content, classroom recordings, field recordings and study support (Belanger 2005).

Apple defines a podcast as "an episodic program delivered via the internet using an XML protocol called RSS" (Apple 2010). The distribution technology used for a podcast is what distinguishes it from other forms of digital audio or video files on the Internet. A podcast is often distributed through a syndication feed, such as a Really Simple Syndication (RSS) feed or a virtual learning environment (VLE). Users can subscribe to podcasts via an RSS feed, so that when new podcasts are released they are downloaded automatically onto a user's computer or mobile device such as an iPod or MP3 player (Beldarrain 2006; EDUCAUSE 2005; Gribbins 2007).

However, in higher education many lecturers deliver their audio files via their universities' VLEs, with or without syndication. The digital audio files developed for this study were all in MP3 format and were delivered via the university's VLE. Students were not required to subscribe to an RSS feed to access the podcasts. In this paper, we have adopted the broader definition of podcast suggested by Salmon et al. (2008), who described a podcast as a digital media file that plays sound or video, is made available from a website and can be downloaded and played on a computer or a portable player.

\section{A review of the literature}

Audio has long been effective in distance education. Durbridge (1984) from the UK Open University identified five key advantages of audio for distance learners: responding to sound as in understanding spoken language; listening in on conversations; being 'talked through' tasks; hearing facts, discussion and opinions from experts in their field; and being encouraged by the voice of someone they know and respect. She concluded that the unique feature of audio over written materials is its ability to influence cognition by adding clarity and motivation, through conveying a sense of immediacy. Audio podcasting offers a means of addressing isolation by bridging the gap between teachers and learners. Isolation experienced by distance learners is a major cause of drop-out across all levels (Peters 1992; Keane et al. 2008). Drop-out rates in distance education typically range from 20 to $50 \%$, depending on the nature and level of the course (see, for example, Xenos, Pierrakeas, and Pintelas 2002; Pierrakeas et al. 2004).

More recently, Salmon and Edirisingha (2008) described a wide range of pedagogical applications of podcasting to support diverse disciplines and subjects. They highlighted the potential of podcasting to bring to learners immediacy, engagement and stimulation (Fothergill 2008), convey more personalised and individualised content (France and Ribchester 2008) and enable students to experience better quality contact with their lecturers (Cox et al. 2008). Podcasts providing input, assessment guidelines and feedback were found effective in supporting students' assessed work (SuttonBrady et al. 2009). Although most of these case studies were based on podcasting to campus-based learners, the same approaches are transferable to distance learning.

Among distance learners, student-created podcasts have succeeded in promoting a sense of belonging to a learning community and in reducing the students' feelings of 
isolation (Lee and Chan 2007; Lee and Tynan 2008). The same study demonstrated the affordance of podcasting in terms of enabling tutors to produce content 'on the fly' and address distance learners' needs in a timely fashion (Lee and Chan 2007, 89). Additional pedagogical benefits attributed to podcasting, as summarised by Lazzari (2009), include significant increases in final project grades and students' receptiveness to material being presented in that format for learning and revision purposes.

A number of challenges associated with podcasting have also been identified, such as students' lack of awareness of the learning potential of this technology and the need for technical support and buy-in from academics (Maag 2006). The "novelty effect" is also mentioned in the literature in relation to podcasts (Hew 2009). Appropriate provision for hearing-impaired students must be made (EDUCAUSE 2005) by making the content available in usable formats that conform to accessibility regulations. Some research suggests that, in certain contexts, podcasts are not popular with learners (Cann 2007) and that they may not affect learning in any significant way (Deal 2007).

As is the case with all new and emerging learning technologies, podcasting may not be appropriate for every teaching and learning context (Beldarrain 2006). However, podcasting can help bridge many gaps in distance education, particularly by improving teacher contact and student support.

\section{Context}

The University of Leicester's School of Psychology is one of the few places in the United Kingdom to offer the opportunity to study OP through distance learning. The OP team started delivering two distance-taught programmes in 2000: the MSc in Occupational Psychology and the Diploma/MSc in the Psychology of Work. Between them, these programmes attract about 50 part-time students per year. Almost all students are in employment throughout their studies. Each programme involves six 20 -credit modules and a 60-credit dissertation over two years. All modules are compulsory. There is no on-campus equivalent of these programmes. From 2000 to 2006, both programmes were delivered through printed materials posted to students, who submitted their assignments and dissertations on paper. They received handwritten summative and formative feedback.

In 2006 the OP team began to develop significantly its use of the Blackboard VLE beyond a document repository to enhance the delivery of the programmes. Initially, the team used Blackboard's discussion board to enable students and staff to communicate and work collaboratively. Tutor-moderated discussion forums provided guidance on the content and assignments for each module. Later, the team extended the use of discussion boards to support and supervise learners at all stages of preparing the dissertation, from initial ideas to final submission. Course materials have now been supplemented with web-based versions and active links to course readings. Blackboard is now the central hub for all student resources. Since 2007 students have submitted their assignments and dissertations through Blackboard's online submission system, and marking by tutors is now fully electronic.

The design and delivery of both OP programmes have seen major developments since 2006. The podcasts were part of a suite of changes as the course moved into its 'second generation'; that is, interactive e-learning as opposed to using the VLE primarily as a repository of materials for distance learners. Podcasts are integral to how the OP tutors teach now and constitute the focus of the research reported here. 
Since 2006 the OP team have been systematically addressing four key challenges in curriculum design and delivery, all common enough in distance learning:

- improving learner engagement with materials and with each other by offering enhanced guidance, support and feedback in a variety of media formats;

- enhancing flexibility in a programme aimed primarily at time-poor work-based learners;

- reducing learner isolation through the provision of additional opportunities for student-student and student-tutor interactions; and

- identifying ways to ensure good retention rates, which can be a particular problem for distance courses.

The team have focused on enhancing the overall learning experience of distance and work-based learners on both programmes. The development and incorporation of podcasts, as reported in this paper, was part of that enhancement.

\section{Podcasting in the Occupational Psychology curricula}

On the basis of previous research on pedagogical applications of podcasting, the OP team, in collaboration with the Beyond Distance Research Alliance, planned, developed and incorporated podcasts into the design and delivery of both postgraduate programmes. Other significant enhancements included the improvement and streamlining of online materials, revised dissertation and early assignment processes, systematic e-moderation of forums, online marking and added quality and consistency in the marking. This suite of changes, gradually implemented between 2006 and 2009, was aimed at addressing the challenges outlined above.

Between April and December 2009, the OP team produced 59 podcasts in five categories (summarised in Table 1): module overview (for two of the modules); research methods; assignment guidance and support; dissertation guidance and support; and formative feedback on draft dissertations. The fifth category was not part of the original project, but was an initiative by the OP team based on their previous podcasting experience.

All learners had access to the module overview, research methods, assignment and dissertation podcasts through the VLE (see Figure 1). Podcasts providing formative feedback on students' dissertation drafts were made available to individual learners. The podcasts in this fifth category were not reusable. However, general feedback points were integrated into the podcasts under the fourth category, which were accessible by all and were reusable across programmes. All podcasts were produced by four members of the OP course team using a free software package called Audacity (http://audacity. download-latest.com), with minimum input from learning technologists.

\section{A podcast planning tool}

A simple tool was used to plan each podcast (see the example in Table 2, used to plan a podcast entitled "What Makes a Good Research Question?"). The grid helped the OP tutors to focus on the purpose and key messages that they wanted to deliver in each podcast.

The maximum recommended length of a podcast is 10 minutes (Edirisingha, Salmon, and Nie 2008). Some of the 59 podcasts feature a single OP tutor but most 
Table 1. Summary of the OP podcasts to December 2009.

\begin{tabular}{|c|c|c|c|}
\hline $\begin{array}{l}\text { Podcast } \\
\text { category }\end{array}$ & $\begin{array}{l}\text { Module(s) to which } \\
\text { podcasts were relevant }\end{array}$ & $\begin{array}{l}\text { Number of } \\
\text { podcasts }\end{array}$ & Purpose \\
\hline \multirow[t]{2}{*}{$\begin{array}{l}\text { Module } \\
\text { overview }\end{array}$} & $\begin{array}{l}\text { Personnel Selection and } \\
\text { Assessment }\end{array}$ & 2 & To provide an overview of the modules \\
\hline & Training and Development & 1 & \\
\hline $\begin{array}{l}\text { Research } \\
\text { methods }\end{array}$ & Research Methods in OP & 11 & $\begin{array}{l}\text { To explain key concepts and approaches } \\
\text { associated with research design, data } \\
\text { gathering and analysis in OP }\end{array}$ \\
\hline \multirow[t]{5}{*}{ Assignment } & $\begin{array}{l}\text { Personnel Selection and } \\
\text { Assessment }\end{array}$ & 4 & $\begin{array}{l}\text { To provide support and detailed guidance } \\
\text { on module assignments, including: }\end{array}$ \\
\hline & Psychology of Organising & 4 & $\begin{array}{l}\text { - clarification of assignment } \\
\text { requirements, }\end{array}$ \\
\hline & Training and Development & 3 & - how to tackle assignments, and \\
\hline & The Individual at Work & 4 & - what markers are looking for \\
\hline & Research Methods in OP & 1 & \\
\hline \multirow[t]{2}{*}{ Dissertation } & Dissertation & 17 & $\begin{array}{l}\text { To guide students through the dissertation } \\
\text { process (see Figure } 1 \text { for a small } \\
\text { sample of these podcasts) }\end{array}$ \\
\hline & & & $\begin{array}{l}\text { To offer a scaffold and pointers to } \\
\text { sources of help }\end{array}$ \\
\hline Feedback & Dissertation & 12 & $\begin{array}{l}\text { To provide individual feedback and } \\
\text { comments on draft dissertation chapters }\end{array}$ \\
\hline
\end{tabular}

\section{Writing the Research Report}

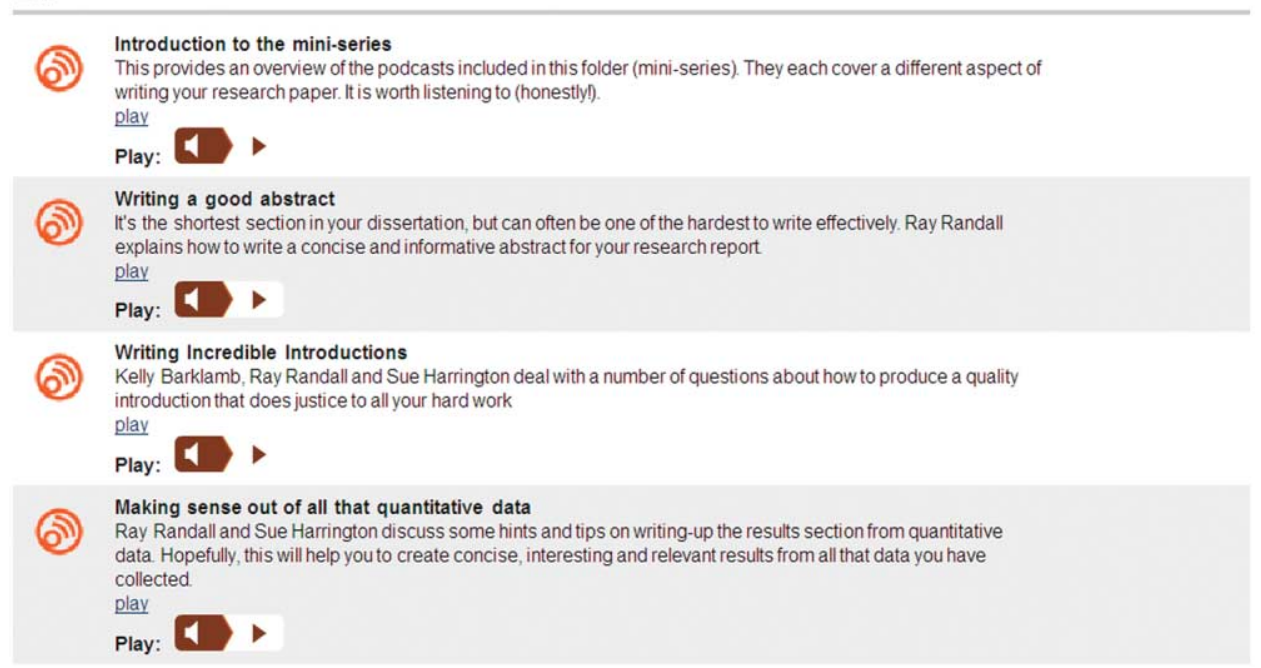

Figure 1. Sample podcasts to support the writing of the dissertation. 
Table 2. Planning tool applied to a Research Methods podcast.

\begin{tabular}{|c|c|c|c|c|}
\hline Section & Purpose & Key concepts & $\begin{array}{l}\text { Length } \\
\text { (minutes) }\end{array}$ & Who \\
\hline 1 & $\begin{array}{l}\text { To highlight the importance of } \\
\text { well-articulated research } \\
\text { questions }\end{array}$ & $\begin{array}{c}\text { Achievable? Researchable? } \\
\text { Novelty or repeat? Too } \\
\text { broad? Narrow enough? }\end{array}$ & 3 & $\mathrm{AS}$ and $\mathrm{KB}$ \\
\hline 2 & $\begin{array}{l}\text { To illustrate the need to explain } \\
\text { the focus of the research }\end{array}$ & $\begin{array}{l}\text { Why is it worth researching } \\
\text { this? What contribution } \\
\text { will this research make? }\end{array}$ & 3 & AS \\
\hline \multirow[t]{4}{*}{3} & $\begin{array}{l}\text { To highlight the need to } \\
\text { demonstrate knowledge of } \\
\text { existing literature covering } \\
\text { earlier research }\end{array}$ & Literature review & 2 & $\mathrm{~KB}$ \\
\hline & & Related topics & & \\
\hline & & Contextual factors & & \\
\hline & & $\begin{array}{l}\text { Creating, challenging } \\
\text { extending }\end{array}$ & & \\
\hline 4 & To recap & $\begin{array}{l}\text { Review of main points } \\
\text { covered }\end{array}$ & 1 & $\mathrm{AS}$ and $\mathrm{KB}$ \\
\hline
\end{tabular}

Note: As = Andrew Shepherd; KB = Kelly Barklamb. Both Andrew and Kelly are tutors of the Occupational Psychology team.

include the input of two, three or four tutors. Although carefully planned and structured, all podcasts are informal and relaxed. They were largely unscripted and designed to motivate and engage OP learners.

\section{Methodology}

In the context of the two OP master's programmes at Leicester, our research question was: what is the contribution of podcasting to curriculum design and delivery? The research was conducted using an action research methodology that involves the “action-reflection" cycle (McNiff and Whitehead 2006, 9). The action-reflection cycle started before the creation of the podcasts. Through surveys and interviews, OP staff and students were consulted on the challenges faced in course design and delivery from the very start of the project. Their views were analysed and results were fed back to the OP team to inform the course redesign. As podcasts were incorporated into the redesign, feedback from students and staff was regularly gathered and analysed. Evidence was fed back to the OP team to inform the next set of design changes.

Before the incorporation of podcasts, all members of the OP staff were consulted on curriculum design and delivery issues through meetings and informal discussions. Semi-structured interviews were conducted with a self-selected sample of seven students to find out the issues and challenges they faced in their studies, their views on how they could be addressed and the role of technology in the possible solutions.

Two VLE-based student surveys were also administered: a standard module survey, and a survey designed to capture learners' ideas on how podcasting might enhance their learning (the "technology survey"). Students were recruited on a voluntary basis. Each respondent was rewarded with a £10 Amazon online voucher. The surveys were completed by students on both OP programmes but from different cohorts (see Tables 3 and 4). 
Table 3. Sample distribution of the online student surveys.

\begin{tabular}{|c|c|c|c|c|}
\hline Survey type & Purpose & $\begin{array}{l}\text { Occupational } \\
\text { Psychology }\end{array}$ & $\begin{array}{l}\text { Psychology } \\
\text { of work }\end{array}$ & $\begin{array}{l}\text { Student } \\
\text { sample }\end{array}$ \\
\hline Module survey & $\begin{array}{l}\text { To evaluate satisfaction with a } \\
\text { specific module, covering: quality } \\
\text { of material, content, reading list, } \\
\text { assessment, support and feedback }\end{array}$ & 18 & 5 & 23 \\
\hline \multirow[t]{3}{*}{$\begin{array}{l}\text { Technology } \\
\text { survey }\end{array}$} & $\begin{array}{l}\text { To find out the level of student } \\
\text { access to technologies such as } \\
\text { computers, the Internet and } \\
\text { personal mobile devices }\end{array}$ & \multirow[t]{3}{*}{25} & \multirow[t]{3}{*}{9} & \multirow[t]{3}{*}{34} \\
\hline & $\begin{array}{l}\text { To establish learners' previous } \\
\text { experience with podcasting and } \\
\text { other technologies }\end{array}$ & & & \\
\hline & $\begin{array}{l}\text { To gather learners' ideas on how } \\
\text { podcasting and other technologies } \\
\text { can be integrated to improve their } \\
\text { learning experience }\end{array}$ & & & \\
\hline
\end{tabular}

Table 4. Sample distribution across cohorts.

\begin{tabular}{lccccc}
\hline & \multicolumn{5}{c}{ Cohort } \\
\cline { 2 - 6 } Survey & October 2007 & April 2008 & October 2008 & April 2009 & Total \\
\hline Module survey & 5 & 2 & 16 & 0 & 23 \\
Technology survey & 5 & 1 & 19 & 9 & 34 \\
\hline
\end{tabular}

After the incorporation of podcasts, evidence collecting was focused on their impact on staff and students. The impact of podcasting on the staff's experience was captured through informal, regular meetings with the OP team. Semi-structured interviews were again conducted with seven students to determine their overall experience of using the podcasts. All seven students had listened to some of the available podcasts and volunteered to be interviewed. Four of them were among the seven who had been interviewed before the incorporation of the podcasts. Data from interviews were supplemented by the comments and feedback contributed by students through the VLE-based surveys and via the discussion board. All the students who were involved in the interview were mature work-based distance learners in full-time employment. Six of the interviewees were female and one was male.

Quantitative data collected from the online surveys were transferred into Excel spreadsheet, and descriptive statistics were applied to close-ended questions. Qualitative data from interviews, surveys and discussion boards were coded using data-driven (inductive) coding (Boyatzis 1998) and analysed using thematic analysis (Boyatzis 1998; Joffe and Yardley 2004) to identify categories and combine categories into themes.

\section{Results}

Podcasting made a major contribution to how the two master's programmes are delivered, and extended the ways in which students were supported. Key findings on the impact of podcasting on students and staff are presented below. 


\section{The human dimension}

The distance learners on these programmes, who were largely work-based, valued highly the production and delivery of personalised content through podcasting. Consultation with students before the incorporation of podcasts showed that, typical for distance learning courses, they perceived a need for more personalisation in the curricula. The evidence showed that podcasting added a human dimension to the learning experience. Compared with reading course materials, articles and textbooks, listening to the tutors' voices added a personal touch and livened up the learning experience. The following student quotations illustrate this:

I feel [a] more personalised service when I can hear the voice from the podcasts. (Survey)

It [podcasting] makes the course less impersonal. For example, listening to the lecturer's voice on podcasts is a big improvement than reading notes. (Survey)

Sometimes it seems cold when you receive [feedback] on paper. In a podcast, [the tutor] says, "you've done well", you can feel something personal. (Interview)

Students considered that listening to a podcast resembled "direct communication". They felt that they received more of their tutors' time and that it was possible to "have a conversation" with them. As a result of that, students felt less "distant" and "isolated", but more "connected" with their tutors.

The most interesting thing was hearing someone's voice. I didn't feel quite so distant. (Survey)

Podcasts made me feel closer to my tutors and I think they help you to build a relationship with them. (Survey)

Over time, by listening to the tutors' voices, learners were able to build a relationship with their tutors, which is often difficult in distance learning.

\section{Support, guidance and feedback}

Podcasts increased learner engagement with the guidance and support that was already available on both programmes. They enabled tutors to convey important and detailed messages in an effective and motivating manner, which was highly appreciated by students. Tutors offered and students benefited from feedback in a way that had not been possible before, which generated a valuable form of interaction between tutors and learners.

Students pointed out that the assignment podcasts "make the instructions clearer"; "give clearer guidance" and "clarify everything". As one student put it:

Thanks for the podcasts. I've found them very helpful. I managed to understand more what we are expected from MA 1 [Module assignment 1]. (Survey)

Students also found listening to the podcasts "consolidating" and "reassuring". Through the surveys, they commented: 
It [the podcast] sets you in the right direction.

It reconfirmed a lot of what I had read already.

It reassured that I was on the right lines.

I feel comfortable that I'm on the right track.

The guidance provided on how to approach dissertations and assignments gave students information that they regarded as useful, for instance, in terms of time management. While this guidance had previously been provided in written format, learners engaged with and related to it differently and positively when it was delivered to them through the tutor's voice.

Podcasting offered tutors a quick and effective mechanism to provide guidance, explanations and feedback. One tutor concluded:

It's amazing how much information you can pack in a 3-5 minute podcast. The material that might take $4-5$ pages to write can be covered in a 4-5 minute podcast. Again, in terms of time-saving, the lecturer may not have 5-6 hours to write something, but he or she has half an hour to do a podcast. (Tutor A)

Another tutor added:

For a 5-minute podcast, I only need to plan half an hour to complete the recording and editing. It's a very fast and efficient way to turn things around. (Tutor B)

The availability of podcasts provided additional opportunities for learners to benefit from guidance, support and feedback in different ways, which helped reduce learner isolation. The value of podcasts and the asynchronous tutor-learner interaction that they foster was universally acknowledged by students.

\section{Flexibility and mobility}

The integration of podcasting into design and delivery also had an impact on the learners' approaches to learning. Surveys and interviews showed that students used the podcasts in various ways. Some listened to the podcasts on computers or laptops at home or in the office. Some played the podcasts on their mobile devices (such as MP3 players, iPods and iPhones) in public places or on the move. The following two quotations illustrate how students used the podcasts, and suggest that podcasting has the potential to address some of the flexibility and mobility challenges in work-based learning that were identified by the OP team:

I use my MP3 player especially for the podcasts. I downloaded them to my MP3 player and listened to them any time on my way. (Interview)

I was able to download the dissertation podcasts on the computer and then onto my iPhone. This made it easy to listen when I had a spare gap. This was useful and enabled me to think things through while I was at work or out. (Survey)

Making podcasts available in formats suited to different mobile devices (including ebook readers with MP3 compatibility) increased flexibility, which was appreciated by the time-poor students on both programmes. 


\section{Design once, deliver many times}

There is indicative evidence that the clarity associated with these podcasts had a positive impact on tutors' workloads. Before the incorporation of podcasts into the curricula, OP students used the VLE discussion boards or email to enquire about administrative, operational and 'housekeeping' issues, many of which had been explicitly addressed in the programme handbook. Tutors reported that students did not always read the handbook. These queries did not require specific academic support. Tutors had the time-consuming and mundane task of dealing, in writing, with similar non-academic questions from students. Although some students still do not make appropriate use of the resources and continue to email standard queries to the team, the podcasts dealt with the vast majority of recurrent issues raised by learners in a clear, friendly and efficient manner. In consequence, tutors perceived a notable reduction in the number of non-academic questions requiring their attention on the discussion board.

The podcasting planning tool (Table 2) was considered useful by the OP tutors. Breaking the podcast into sections helped them to stay focused on the key objectives. As they grew more and more familiar with the technology and as they gained production experience, tutors adopted, over time, an informal, unscripted style that engaged and motivated learners. Tutors were able to 'design once and deliver many times' by transferring content between podcasts with minimum adaptation and versioning, which has contributed to the sustainability of the innovation.

Allowing for individual differences within the team, OP tutors generally found creating podcasts easy, quick and intuitive. Using free, stable software and their own voices, they were able to offer students support, guidance and personalised feedback in a cost-effective manner.

\section{Discussion}

This paper has reported on the contribution of podcasting to curriculum transformation in two OP programmes at the University of Leicester. Table 5 captures the key points associated with each of the main findings.

Table 5. Summary of key research findings.

\begin{tabular}{ll}
\hline Findings & Key points \\
\hline $\begin{array}{l}\text { The learner experience } \\
\text { The human touch }\end{array}$ & - Personalisation, interaction, relationship-building \\
& - Livening up the learning experience \\
& learning in the isolation associated with distance \\
$\begin{array}{l}\text { Guidance, support and feedback } \\
\text { in different formats }\end{array}$ & - Effective provision of feedback, guidance and \\
& - support in different formats \\
Flexibility and mobility & - Access to quality content through mobile devices \\
Innovation and sustainability & \\
Design once, deliver often & - Reusability of resources, minimum adaptation \\
& - Low-cost, high-value innovation \\
& - Reduced online traffic on non-academic matters \\
& - Transferability of frameworks and lessons learned
\end{tabular}


Learners were overwhelmingly satisfied with the incorporation of podcasts into the curricula. They appreciated the added human touch and the opportunities to engage with the material differently. In interviews, online surveys and contributions to the discussion board, students used words such as "excellent", "very helpful", "very useful", "motivating", "beneficial" and "reassuring" to describe their positive experience of using the podcasts. The other technologies used in the project did not interfere with the high use of podcasts by students or with the production of podcasts by staff. The tutors' commitment to innovation and curriculum renewal was outstanding throughout the process.

\section{Limitations}

Most higher education institutions choose to deliver podcasts through their VLEs, as this is considered to be an environment that is both secure and familiar to staff and students. In our case, making podcasts available through the university's VLE offers another advantage: through the Blackboard Content Collection, staff can share podcasts across different cohorts and departments. The Content Collection is an institutional content repository, capable of supporting the sharing of content amongst courses and modules within the VLE. However, at the time of writing, RSS feeds were not available on our institutional version of Blackboard. Students have to log in to the VLE to download the podcasts onto their computers and mobile devices. Thus, podcasting has so far been used as a 'pull' rather than a 'push' technology (i.e. no syndication feeds have been used).

Data collected after the incorporation of podcasts show that many students listened to podcasts on their portable mobile devices, indicating the potential of podcasting to enhance the mobility and flexibility of student learning (Salmon and Nie 2008). However, data from student interviews and surveys and informal comments from the Blackboard discussion forum indicated that not every student was aware of the possibility of using podcasts on portable devices. Further research is needed to establish the extent to which this awareness would translate into added benefit for learners.

\section{Institutional transformation}

The research into the impact of the curriculum redesign interventions described here, including the incorporation of podcasts into the OP curricula, has shown tangible and transferable benefits to students and staff, while promoting pedagogical innovation.

This kind of positive change is spreading at the University of Leicester. Pro-active internal dissemination of findings undertaken by the OP team and the Beyond Distance Research Alliance, including Media Zoo events (Armellini, Salmon, and Hawkridge 2009), through the University's Assessment and Feedback Working Party, the Distance Learning Forum, Learning Futures Festival ${ }^{2}$ and the PANTHER seminar $^{3}$ have taken the outcomes of this research to other parts of the university. Evidence gathered through the DUCKLING project and exemplars from the OP redesign experience have featured prominently in all of these events, which have constituted excellent opportunities for sharing experiences and research findings in technology-enhanced curriculum transformation and delivery. Academic and support staff from across the university have actively participated in the events, and continue to do so. 
Exposure to researched exemplars from the OP experience has motivated others to consider the incorporation of podcasting into curriculum design and delivery. So far, practitioners from six departments (Criminology, Engineering, Law, Lifelong Learning, Management, and Media and Communications) are now either redesigning parts of their curricula by making use of podcasting or planning changes that may, in future, incorporate the findings of this research. On the evidence from DUCKLING and earlier podcasting projects, this technology is being used in creative ways to enhance learners' experiences and improve efficiency across the institution.

The new Learning Innovation Strategy, approved by the University Senate in 2009, provides an appropriate context for these innovations to take place in a supported way across the institution. Through internal, national and international dissemination, including conferences, publications and a significant online presence, our research into podcasting continues to inform institutional transformation and innovation well beyond the University of Leicester.

\section{Future research}

The introduction of podcasts into both OP curricula was, as reported above, one of a suite of coordinated measures aimed at enhancing the experience of distance and work-based learners. Retention and the quality of assessed work in relation to curriculum renewal and pedagogical innovation have emerged as two key areas for future work. Firm conclusions on them can only be reached over time and after several cohorts have completed the programmes. Indicative evidence suggests that - as a result of the curriculum enhancement process - retention has marginally improved, as has the quality of the dissertation drafts. An impact on these, if confirmed by future research, should be attributed to the range of curriculum design and delivery changes implemented by the OP team in recent years, of which one was the podcasting.

\section{Conclusions}

This article provided an example of the effective use of podcasting within an ambitious curriculum renewal initiative involving two master's distance learning programmes in OP aimed at work-based learners. The evidence shows that podcasting has enhanced the learner experience by offering added personalisation, opportunities to benefit from content presented in a new format, increased curriculum flexibility and cost-effectiveness. The research and its proactive dissemination have highlighted the sustainability and transferability of these approaches to other institutional contexts.

The presentation of research evidence in a variety of usable formats has enabled others across the university to relate to exemplars, to adapt and test the ideas in their own courses and contexts, and to promote pedagogical innovation. We will continue to research the role of learning technology in institutional transformation through curriculum renewal and make our findings available for the benefit of the institution and the academic community.

\section{Acknowledgements}

This research was part of a Joint Information Systems Committee-funded research project called DUCKLING (Delivering University Curricula: Knowledge, Learning and INnovation Gains) (http://www.le.ac.uk/duckling). DUCKLING aimed to enhance the experience of 
work-based learners studying at a distance through the appropriate incorporation of three technologies: podcasting, Second Life and e-book readers. The two masters in OP and one in Applied Linguistics and TESOL were the target programmes for the innovations to be implemented and researched. In this article we report on the first innovation; that is, the incorporation of podcasts into the OP programmes. The research was led by the Beyond Distance Research Alliance, a separate research unit at University of Leicester.

\section{Notes}

1. Duke Digital Initiative. http://www.duke.edu/ddi/.

2. Learning Futures Festival. http://www.le.ac.uk/beyonddistance/festival.

3. PANTHER. http://bit.ly/9k6E5C.

\section{References}

Apple. 2010. FAQs: For podcast fans. http://www.apple.com/itunes/podcasts/fanfaq.html.

Armellini, A., G. Salmon, and D. Hawkridge. 2009. The Carpe Diem journey: Designing for learning transformation. In Transforming higher education through technology-enhanced learning, ed. T. Mayes, D. Morrison, H. Mellar, B. Peter, and O. Martin, 135-48. York: The Higher Education Academy.

Belanger, Y. 2005. Duke iPod first-year experience. Duke Centre for Instructional Technology. http://www.cit.duke.edu/pdf/ipod_initiative_04_05.pdf.

Beldarrain, Y. 2006. Distance education trends: Integrating new technologies to foster student interaction and collaboration. Distance Education 27, no. 2: 139-53.

Boyatzis, R.E. 1998. Transforming qualitative information: Thematic analysis and code development. London: Sage.

Cann, A.J. 2007. Podcasting is dead. Long live video! Bioscience Education e-Journal 10. http://www.bioscience.heacademy.ac.uk/journal/vol10/beej-10-c1.pdf.

Cox, B., R. Macharia, N. Short, and K. Whittlestone. 2008. Podcasts and resources. In Podcasting for learning in universities, ed. G. Salmon and P. Edirisingha, 103-12. Maidenhead: Open University Press, McGraw-Hill Education.

Deal, A. 2007. Podcasting. A teaching with technology White Paper. Carnegie Mellon University. http://www.cmu.edu/teaching/resources/PublicationsArchives/StudiesWhite papers/Podcasting_Jun07.pdf.

Durbridge, N. 1984. Media in course design, No.9, audio cassettes. In The role of technology in distance education, ed. A.W. Bates, 99-108. Beckenham, UK: Croom Helm.

Edirisingha, P., G. Salmon, and M. Nie. 2008. Developing pedagogical podcasts. In Podcasting for learning in universities, ed. G. Salmon and P. Edirisingha, 153-68. Maidenhead: Open University Press, McGraw-Hill Education.

EDUCAUSE. 2005. Seven things you should know about podcasting. EDUCAUSE Learning Initiative. http://net.educause.edu/ir/library/pdf/ELI7003.pdf.

Fothergill, J. 2008. Podcasts and online learning. In Podcasting for learning in universities, ed. G. Salmon and P. Edirisingha, 80-91. Maidenhead: Open University Press, McGrawHill Education.

France, D., and C. Ribchester. 2008. Podcasts and feedback. In Podcasting for learning in universities, ed. G. Salmon and P. Edirisingha, 70-9. Maidenhead: Open University Press, McGraw-Hill Education.

Gribbins, M. 2007. The perceived usefulness of podcasting in higher education: A survey of students' attitudes and intention to use. Paper presented at the Second Midwest United States Association for Information Systems, May 18-19, in Springfield, IL. https:// edocs.uis.edu/mgribbin/www/MWAIS2007paper.pdf.

Hew, K.F. 2009. Use of audio podcast in K-12 and higher education: A review of research topics and methodologies. Educational Technology Research and Development 57, no. 3 : 333-57.

Joffe, H., and L. Yardley. 2004. Content and thematic analysis. In Research methods for clinical and health psychology, ed. D.F. Marks and L. Yardley, 56-68. London: Sage.

Keane, J., C. de la Varre, M.J. Irvin, and W. Hanum. 2008. Learner-centred social support: Enhancing online distance education for underserved rural high school students in the 
United States. Paper presented at the Association for Learning Technology Conference, September 9-11, in Leeds, UK.

Lazzari, M. 2009. Creative use of podcasting in higher education and its effect on competitive agency. Computers \& Education 52, no. 1: 27-34.

Lee, M.J.W., and A. Chan. 2007. Reducing the effects of isolation and promoting inclusivity for distance learners through podcasting. Turkish Online Journal of Distance Education 8, no. 1: 85-104.

Lee, M.J.W., and B. Tynan. 2008. Podcasts and distance learning. In Podcasting for learning in universities, ed. G. Salmon and P. Edirisingha, 92-102. Maidenhead: Open University Press, McGraw-Hill Education.

Maag, M. 2006. Podcasting and MP3 players: Emerging education technologies. Computers Informatics Nursing 24, no. 1: 9-13.

McNiff, J., and J. Whitehead. 2006. All you need to know about action research. London: Sage Publications.

Peters, O. 1992. Some observations on dropping out in distance education. Distance Education 13, no. 2: 234-69.

Pierrakeas, C., M. Xenos, C. Panagiotakopoulos, and D. Vergidis. 2004. A comparative study of dropout rates and causes for two different distance education courses. International Review of Research in Open and Distance Learning 5, no. 2. http://www.irrodl.org/ index.php/irrodl/article/viewArticle/183.

Salmon, G., and P. Edirisingha, eds. 2008. Podcasting for learning in universities. Maidenhead: Open University Press, McGraw-Hill Education.

Salmon, G., R. Mobbs, P. Edirisingha, and C. Dennett. 2008. Podcasting technology. In Podcasting for learning in universities, ed. G. Salmon and P. Edirisingha, 20-32. Maidenhead: Open University Press, McGraw-Hill Education.

Salmon, G., and M. Nie. 2008. Doubling the life of iPods. In Podcasting for learning in universities, ed. G. Salmon and P. Edirisingha, 1-11. Maidenhead: Open University Press, McGraw-Hill Education.

Sutton-Brady, C., K.M. Scott, L. Taylor, G. Carabetta, and S. Clark. 2009. The value of using short-format podcasts to enhance learning and teaching. ALT-J, Research in Learning Technology 17, no. 3: 219-32.

Xenos, M., C. Pierrakeas, and P. Pintelas. 2002. A survey on student dropout rates and dropout causes concerning the students in the course of Informatics of the Hellenic Open University. Computers \& Education 39, no. 4: 361-77. 